\title{
Małgorzata Okupnik, W niewoli ciała. Doświadczenie utraty zdrowia i jego reprezentacje, Universitas, Kraków 2018, ss. 553
}

Wydana w 2018 roku monografia Małgorzaty Okupnik W niewoli ciata. Doświadczenie utraty zdrowia i jego reprezentacje stanowi pionierską na gruncie polskiego literaturoznawstwa próbę opracowania tekstów poświęconych doświadczeniu długotrwałego chorowania. Wyróżnią ją objętość, a także zawarte w niej analizy wybranych narracji maladycznych autorstwa profesjonalnych pisarzy (przypadek Krystyny Kofty), artystów (przypadek Józefa Czapskiego) oraz chorych wykorzystujących nowe, niekonwencjonalne formy komunikacji z czytelnikami (przypadek Joanny Sałygi, która zmagania z rakiem relacjonowała na blogu Do czego przyda się chustka?). Choć równie często interesuje badaczkę to, jakie strategie wybierają poszczególni autorzy, oraz to, co piszą ze świadomością, że pozostało im niewiele czasu do zagospodarowania, to jednak należy podkreślić, że Okupnik w każdym z rozdziałów poszukuje odpowiedzi na pytanie o epistemologiczny potencjał cierpienia, utraty i długotrwałego odczuwania bólu.

Za jedną z pierwszych publikacji, których celem było sondowanie nowego obszaru badawczego (studiów maladycznych), można uznać książkę Iwony Boruszkowskiej Defekty. Literackie auto/pato/grafie - szkice, wydaną w 2016 roku, jednak to właśnie książka Okupnik stanie się najważniejszym punktem wyjścia kolejnych badaczek i badaczy ze względu na rzetelne i mikrologiczne opracowanie tematu (jedyny zarzut, jaki można postawić omawianej rozprawie, dotyczy braku rozdziału poświęconego poetyckim reprezentacjom bólu, których sukcesywnie przybywa ${ }^{1}$ ) i wykorzystanie wielu propozycji metodologicznych (m.in. tanatologii, somatoestetyki, antropologii literatury, studiów nad traumą), a także koncepcji

1 W 2009 roku ukazała się książka Krystyny Pietrych Co poezji po bólu. Empatyczne przestrzenie lektury, jednak od momentu jej opublikowania pojawiło się kilka książek poetyckich sondujących doświadczenie bólu, choroby i utraty. 
wypracowanych na gruncie innych dyscyplin (przypadek „smug Zagłady” autorstwa Beaty Przymuszały). W niewoli ciata to książka napisana w sposób przystępny, z zachowaniem reguł obowiązujących w badaniach naukowych (o erudycji autorki świadczą obszerne przypisy). W każdym rozdziale prezentowany jest stan badań, jednak wybór autorów znanych i omówionych w innych publikacjach nie wpłynął na jakość tez stawianych przez literaturoznawczynię, która każdorazowo precyzyjnie określa cel analiz i śledzi momenty przełomowe i kryzysowe w narracjach maladycznych.

Przedsięwzięcie Okupnik jest ambitne przynajmniej z trzech powodów. Po pierwsze, w trakcie prac badaczki nad monografią studia maladyczne nie były w Polsce dyscypliną cieszącą się tak dużym jak dziś zainteresowaniem (wystarczy wspomnieć, że od 2018 roku pojawiły się trzy książki eksplorujące podobny obszar badawczy: w 2019 roku ukazała się publikacja Choroba jako literatura. Studia maladyczne autorstwa Moniki Ładoń, w tym samym roku na rynku wydawniczym pojawiła się monografia wieloautorska Fragmenty dyskursu maladycznego pod redakcją Macieja Ganczara, Ireneusza Gielaty i Ładoń, a w 2020 roku wydawnictwo Universitas opublikowało książkę Sebastiana Porzuczka Mapowanie bólu. Lektura - spojrzenie - afekt). Po drugie, przedstawiciele studiów maladycznych nie wykorzystują jednej, wiodącej metodologii, lecz preferują pluralizm metodologiczny, który umożliwia poszukiwanie nowych sposobów interpretacji artefaktów. Po trzecie, zajmowanie się tym obszarem literatury, który ze względu na pakt autobiograficzny wykracza poza ramy fikcyjnych opowieści i zmusza do badania zapisów osób wiedzących, że ich życie dobiega końca, budzi wątpliwości równie silne jak studiowanie literatury wojennej (w tym Zagłady). Literaturoznawca, komentując zapis skończonej egzystencji, przyjmuje postawy podglądacza i niedyskretnego obserwatora, które cechuje obiektywizm i nieczułość na fakt, że zapis cierpienia nie powinien podlegać ocenie oraz wartościowaniu. Drugim możliwym niebezpieczeństwem związanym ze studiowaniem literatury maladycznej jest zjawisko fałszywej identyfikacji i substytucji, o którym w kontekście badań nad Zagładą pisała Dorota Krawczyńska w artykule Empatia? Substytucja? Identyfikacja? Jak czytać teksty o Zagtadzie?, opublikowanym w piątym numerze „Tekstów Drugich” z 2004 roku. Okupnik zdaje sobie jednak sprawę z niebezpieczeństw, jakie czyhają na potencjalnych krytyków i kolejnych badaczy chcących dezawuować formę zapisu i autorskie decyzje o epatowaniu szczegółami dotyczącymi procesu utraty sił i kolejnych organów pojawiającymi się w tekstach autobiograficznych/intymistycznych.

Mimo że $W$ niewoli ciata składa się z autonomicznych rozdziałów, które przyjęły formę case studies, badaczka zdecydowała się na poprzedzenie wnikliwych analiz obszernym wstępem. Decyzja ta jest w pełni uzasadniona, ponieważ już w samym tytule pojawia się pięć zagadnień modelujących jej wywód, a w kolejnych częściach rozbudowanego wstępu kata$\log$ pojęć został jeszcze poszerzony o kilka kolejnych (m.in. świadectwo, narrację, empatię, patografię). Kategoriami, którym Okupnik poświęca szczególną uwagę, są: reprezentacja, utrata, zdrowie, doświadczenie, osobną część poświęciła ona sposobom przedstawiania choroby w patografiach (wyróżnia m.in. karę, walkę i winę oraz podróż).

Dzięki temu, że monografia została podzielona na trzy części, z których dwie pierwsze (O utracie i Kulturowy wymiar doświadczenia utraty zdrowia) zawierają ustalenia teoretyczne, a ostatnia (Reprezentacje doświadczenia utraty zdrowia) analizy wybranych strategii pisania o chorym ciele (wśród schorzeń dominuje kilka odmian nowotworu), możliwe jest śledzenie dwóch komplementarnych narracji. Pierwsza koncentruje się na poszukiwaniu 
adekwatnych narzędzi z pogranicza literaturoznawstwa i kulturoznawstwa do badania intymnych zapisów zmagania człowieka $\mathrm{z}$ własną skończonością, druga natomiast prezentuje sztukę interpretacji tekstów wymagających szczególnej ostrożności i taktu. Podstawowym zadaniem, jakie postawiła przed sobą badaczka, jest prześledzenie sposobów oswajania się pacjentów z chorobą i możliwością utraty życia, a także odnajdywanie momentów szczęścia (felicytologia) w sytuacjach granicznych. Choć jak podkreśla badaczka w zakończeniu: „Doświadczenie utraty nie ma kanonu, jest nieinteligibilne, zindywidualizowane, tak jak różni są ludzie i ich życiorysy” (s. 492), wszystkie przeprowadzone przez nią analizy przeczą tezie o tym, że utraty nie można zrozumieć. Sami autorzy rozumieją, co tracą i jak utrata (zdrowia/piersi/atrakcyjnego wyglądu/ukochanej osoby) wpłynie na dalsze życie. Aktywność literacka pomogła im jednak dojść do wniosków, które być może nigdy nie pojawiłyby się, gdyby nie konieczność zmierzenia się z bolesnym doświadczeniem. W części wprowadzającej Okupnik pisze: „[...] narracje o utracie są tworzone z pewnego dystansu czasowego, [...]. Ich celem jest doszukiwanie się sensu w bezsensie » sytuacji granicznej « (czyjejś śmierci bądź utraty zdrowia). Bywają formą autoterapii (czy arteterapii)” (s. 159).

Biorąc pod uwagę analizy wybranych patografii, można stwierdzić, że choroba wpływa w znaczny sposób nie tylko na postrzeganie własnego ciała, relacji z bliskimi i niedogodności, na jakie narażeni są chorzy, lecz również na dowartościowanie tych aspektów życia, które dotąd pozostawały niedostrzegalne. Mimo że nie zawsze piszą oni expressis verbis o chorobie jako przyczynie transformacji, to jednak długotrwały stan wiwisekcji związany z chęcią wykrycia dalszych zmian i przerzutów pozwala na poszukiwanie momentów ułatwiających zrozumienie sensu, jaki wyłania się z sytuacji groźnych, destrukcyjnych i niekomfortowych.

Książka Okupnik poświęcona została doświadczeniu, które choć z pozoru nieuchwytne (choroba może pojawić się w nieoczekiwanym momencie lub w sposób nieodczuwalny dla pacjenta niszczyć jego organy i powodować spadek aktywności intelektualnej i fizycznej), całkowicie zmienia percepcję chorego oraz jego stosunek do świata i otoczenia. Nie wszystkim autorom tekstów, które gruntownie omówiła literaturoznawczyni, udało się wyzdrowieć (Sałyga była pacjentką terminalną), dla niektórych choroba była rozpisanym na kolejne etapy umieraniem (przypadek Henryka Daski i Johna Diamonda) i inni zaś powrócili do stanu równowagi, czyli zdrowia, jednak ze względu na własne przeżycia, stali się ambasadorami w sprawie profilaktyki zdrowotnej i własną postawą wobec choroby wyznaczyli wzory zachowań oraz pożądanych postaw (przypadek Krystyna Kofty i Jerzego Stuhra). To właśnie moment ujawnienia informacji o złym stanie zdrowia (bez względu na formę wypowiedzi) jest kluczowy, ponieważ pozwala na zawiązanie z odbiorcami paktu zaufania. W przypadku osób publicznych chorowanie - mimo że zmusza do stawiania czoła wyzwaniom w asyście obserwatorów - pozwala na stanie się przykładem niezłomnej postawy wobec kolejnych komplikacji i upokorzeń (Ładoń nazwała Koftę „onkocelebrytką”2). Odzew, jaki wywoła informacja o konieczności wykonywania badań, wart jest podjęcia decyzji o porzuceniu prywatności (podjęcie wyzwania ${ }^{3}$ spisania własnej historii jest równoznaczne z udzieleniem czytelnikom zgody na śledzenie dalszych etapów leczenia).

Choroba pozwala na rewizję sądów na temat wydolności organizmu i dostrzeżenie kruchości zarówno jednostki, jak i rodziny jako grupy ludzi towarzyszącej pacjentowi

2 M. Ładoń, Choroba jako literatura. Studia maladyczne, Katowice 2019, s. 135.

3 Zob. M. Czermińska, Autobiograficzny trójkąt. Świadectwo - wyznanie - wyzwanie, Kraków 2000. 
oraz troszczącej się o jego samopoczucie. Fenomen choroby interesuje literaturoznawców z dwóch powodów: po pierwsze, określanie stanów patologicznych i dysfunkcyjnych organizmu jako jednoznacznie negatywnych utrudnia dostrzeżenie ich wartości rewelatorskiej (pozwalają na weryfikację wielu sądów, a także poddanie się zmianom mającym długotrwałe konsekwencje zarówno pod względem fizycznym, jak i psychicznym). Po drugie, choroba to stan, w którym prędzej czy późnej znajdzie się każdy człowiek, a więc zaniechanie badań strategii opisu zmagania z czymś, co pozornie przynależy do ciała, lecz na skutek mutacji stało się intruzem oraz zagraża zdrowiu i życiu, uniemożliwiłoby skonstatowanie najważniejszej prawdy, jaka pojawia się w każdej analizowanej przez Okupnik patografii: „Choremu ciało jawi się inaczej niż osobie zdrowej. Człowiek zdrowy i sprawny nie czuje swojego ciała (to jest jego niedomagań), chory — przeciwnie. Zasadnicza różnica polega na tym, że zdrowy myśli raczej o sobie, nie zaś o swoim ciele; człowiek chory nie może natomiast myśleć o sobie, gdyż jego ciało zmusza go do myślenia jedynie o nim. W przypadku chorego ciało nie jest problemem teoretycznym, lecz praktycznym" (s. 89).

Monografia Małgorzaty Okupnik pozwala na zakwestionowanie dotychczasowego sposobu waloryzacji zdrowia i choroby (załamanie się stanu zdrowia powoduje większą wrażliwość na to, co otacza człowieka) i zaakcentowanie prawdy, która niczym wiedza o koniecznej śmierci wypierana jest z przestrzeni publicznej, że ból, będący samą cielesnością (s. 139), jest niezbywalnym elementem życia, podobnie jak stany patologiczne i cielesne ułomności. Transformacyjny potencjał defektu (chwilowego, np. utraty narządu lub długotrwałego) jeszcze nigdy nie stał się przedmiotem tak wieloaspektowych i mikrologicznych analiz. $W$ niewoli ciata można traktować jako zaprojektowany z myślą o wszystkich instruktaż zachowań wobec chorego, który w narracji Okupnik pozostaje „niedotykalnie drogi”.

ANDRZEJ JUCHNIEWICZ 